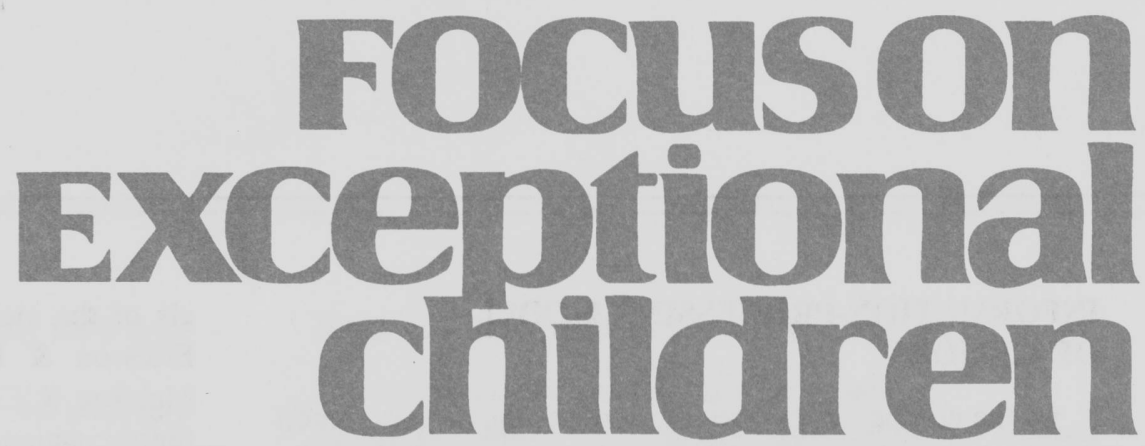

\title{
Strategies to Enhance Memory Based on Brain-Research
}

\author{
Alison K. Banikowski and Teresa A. Mehring
}

Memory is a wonderful trait of human beings. Now, more than ever in history, scientists are unlocking the secrets to enhancing memory. Memory is extremely important to educators, not only for them personally as they age and worry about failing memory, but, most important, for the role that memory plays in the teaching/learning process. Memory, as a concept, often is relegated to a minimal role. As noted by Caine and Caine (1997), "Many of us associate the word memory with the recall of specific dates or facts or lists of information and sets of instructions, requiring memorization and effort" (p. 41). Memory, however, goes beyond this one-dimensional aspect of learning and, rather, focuses on attending, learning, linking, remembering, and using the thousand pieces of knowledge and skills we encounter constantly. For educators, memory is the only evidence that something or anything has been learned.

Think about it. If students cannot commit knowledge or skills to memory, even briefly, how can we know they have learned the knowledge or skill? It conjures up visions of the cartoon where two boys are talking. The one boy, with his dog at his side, says, "I"ve taught my dog how to whistle," and the other little boy says, "Great! Let me hear him whistle." This prompts the first boy to say, "I said I taught him how to whistle. I didn't say he learned it!"

For educators, what's the point? If teaching occurs without learning, we might as well skip the teaching in the first place! Educators must ensure that students attend to learning, attach new learning to previous learning, actively engage in learning, construct meaning, and demonstrate their learning. All of this requires memory. No true educator simply wants to "teach"; educators want students to "learn." Educators want learners to be able to organize, store, and retrieve knowledge and skills. By applying what we know about how the brain learns and remembers, educators can focus on the "learning" aspect of the "teaching/learning process." To assist educators, this article will focus on three aspects related to memory:

- An information processing model of memory,

- Instructional strategies designed to enhance memory,

- Reasons why we forget.

Alison K. Banikowski is the Assistant Superintendent for Curriculum and Instruction, Olathe School District, Olathe, Kansas. Teresa (Tes) Mehring is the Dean of the Teachers College, Emporia State University. 


\section{INFORMATION-PROCESSING MODEL OF MEMORY}

Of the number of theories of memory, the most common are the information-processing explanations, including the newer neural-network or connectionist approaches (Woolfolk, 1998). The information-processing model is based on processing and interpreting sensory data and converting these data into a form that can be recalled later. Interpreting sensory input includes determining whether it is to be remembered and its relationship to past knowledge, and then storing it in retrievable form. Information processing, which had its origins in communication and computer science, suggests that mental processes (like memory) can be interpreted as a flow of information through various stages (Matlin, 1989).

The information-processing model is based on the processing and interpreting of sensory data and the converting of such data into a form that can later be recalled. Most information-processing models of memory have three major components: a sensory register, a working (or short-term) memory, and a long-term memory. Several theorists have published visual diagrams of information-processing mod-

\section{Focuson
Exceptional children}

ISSN $0015-511 \mathrm{X}$

FOCUS ON EXCEPTIONAL CHILDREN (USPS 203-360) is published monthly except June, July, and August as a service to teachers, special educators, curriculum specialists, administrators, and those concerned with the special education of exceptional children. This publication is annotated and indexed by the ERIC Clearinghouse on Handicapped and Gifted children for publication in the monthly Current Index to Journals in Education (CIJE) and the quarterly index, Exceptional Children Education Resources (ECER). The full text of Focus on Exceptional Children is also available in the electronic versions of the Education Index. It is also available in microfilm from Xerox University Microfilms, Ann Arbor, MI. Subscription rates: Individual, \$30 per year; institutions, \$40 per year. Copyright (C) 1999, Love Publishing Company. All rights reserved. Reproduction in whole or part without written permission is prohibited. Printed in the United States of America. Periodicals postage is paid at Denver, Colorado. POSTMASTER: Send address changes to:

Love Publishing Company

Executive and Editorial Office P.O. Box 22353

Denver, Colorado 80222

Telephone (303) 221-7333
Edward L. Meyen University of Kansas

\section{Glenn A. Vergason} Georgia State University els of the memory process (Atkinson and Shiffrin, 1968; Ericsson \& Kintsch, 1995; Massaro \& Cowan, 1993, Mehring \& Colson, 1993). Figure 1 presents a schematic representation of the memory process incorporating key elements of the theorists who have written extensively about memory from an information-processing perspective.

\section{Sensory Register}

Contemporary information processing theory studies the process of learning as a system of brain functions (Reed, 1992). Students' primary contact with the information and knowledge they are expected to learn is through their sense receptors (Henson and Eller, 1999). Sense receptors are defined as those sense organs that allow us to make contact with our environment (Santrock, 1997).

Students listen to their teachers (ears), read texts (eyes), smell food in the school cafeteria (nose), taste their afterschool snack (tongue), and write or model with clay (hands) (Henson and Eller, 1999, p. 249).

Stimuli from the environment are bombarding our sensory receptors constantly. The sensory register, sometimes also referred to as sensory memory or the sensory informa-

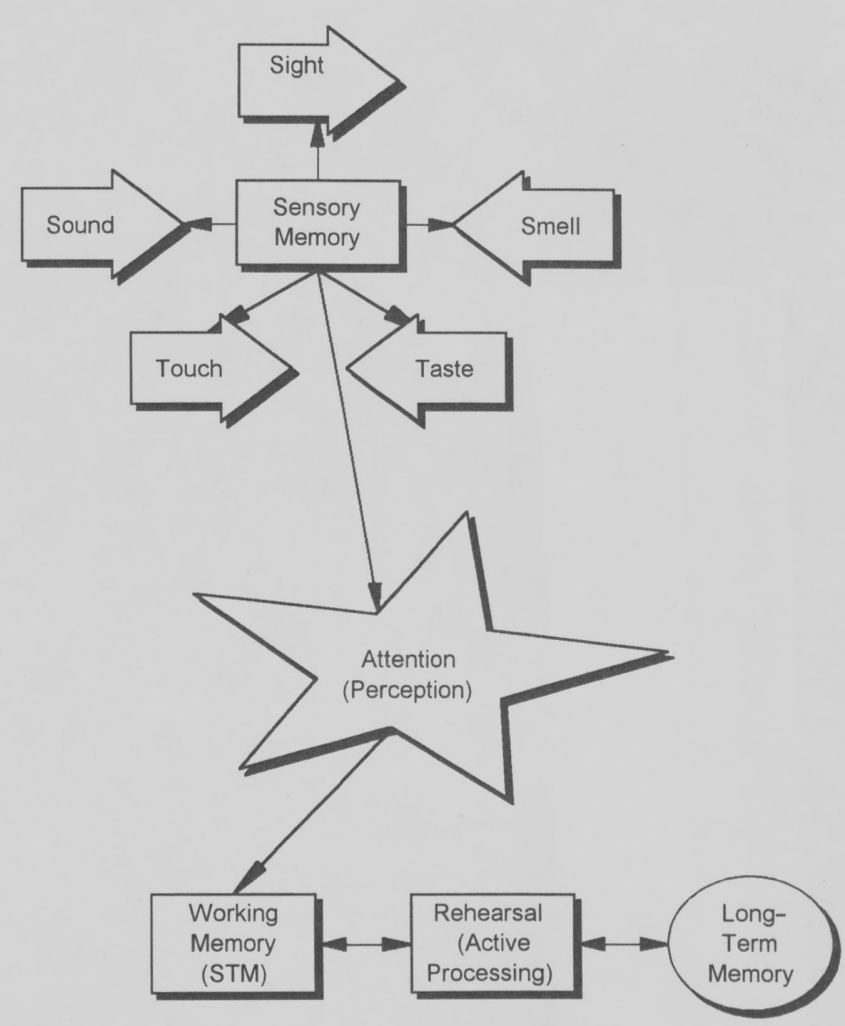

Figure 1 Information Processing Model for Memory 
tion store, holds all of these sensations, but only for a brief time.

The sensory register has a large capacity and probably can hold everything the body is capable of seeing, hearing or sensing (Ormrod, 1998). The bad news is that the information stored in the sensory register doesn't last long (Winfield \& Byrnes, 1981). Duration is only 1 to 4 seconds. Visual information lasts less than 1 second, tactile information 2 to 3 seconds, and auditory information up to $4 \mathrm{sec}$ onds (Henson \& Eller, 1999). If nothing is done to actively focus attention held in the sensory register, it is lost rapidly.

Many theorists believe that attention plays a key role in moving information from the sensory register to working (short-term) memory. Basically, whatever an individual pays attention to moves into working memory (Ormrod, 1998). Anything in the sensory register that does not get a person's attention disappears from the memory system.

\section{Attention}

Unfortunately, people can attend to only a small amount of information at any one time. People often can perform two or three well-learned, automatic tasks at one time (e.g. driving a car and drinking a soda at the same time). When a stimulus or event is detailed and complex or when a task requires considerable thought (e.g., understanding directions to a location not visited before), people usually can attend to only one thing at a time (J.R. Anderson, 1995). Because of the limited capacity of human attention, only a small amount of information stored in the sensory register ever moves on to working memory. The vast majority of information that the body receives initially is lost quickly from the memory system.

The sensory register has two important educational implications:

\begin{abstract}
First, people must pay attention to information if they are to retain it. Second, it takes time to bring all the information seen in a moment into consciousness. For example, if students are bombarded with too much information at once and are not told which aspects of the information they should pay attention to, they may have difficulty learning any of the information at all (Slavin, 1997, p. 186)
\end{abstract}

\section{Working (Short-Term Memory)}

Working memory is the component of memory where new information is held while it is mentally processed. It is a temporary holding bin for new information. It also is the component where much of our thinking, or information processing, takes place. It is where we try to make sense of a lecture, understand a textbook passage, or solve a problem. Working memory is the component that probably does most of the processing, or "work," of the memory system (Ormrod, 1998).
It has two characteristics that are worth noting:

1. It screens information that comes into it.

2. It is limited in capacity and duration. Without rehearsal, it can hold about five to nine items for about 10 to 20 seconds in adults (Gagne, Yekovich \& Yekovich, 1993).

Figure 2 provides a developmental perspective illustrating the number of new bits of information young children and adolescents can hold in working memory at any given time. Consider also the impact a cognitive disability might have on working memory.

Because information in working memory is fragile and easily lost, it must be kept activated to be retained. Activation is high as long as you are focusing on information, but activation decays or fades quickly when attention shifts away. To keep information activated in working memory for longer than 20 seconds, individuals can rehearse the information mentally. There are two types of rehearsal (Craik \& Lockhart, 1972):

1. Maintenance rehearsal involves repeating the information in your mind. As long as you repeat the information, you can maintain it in your working memory indefinitely. Maintenance rehearsal is useful for retaining something you plan to use and then forget, such as a phone number.

2. Elaborative rehearsal involves connecting the information you are trying to remember with something you already know, with information from long-term memory (Woolfolk, 1998).

For example, if you meet someone at a social function who has the same name as your mother, you don't have to

\begin{tabular}{|l|l|}
\hline Age & Bits of Information \\
\hline 5 & 2 \\
\hline 7 & 3 \\
\hline 9 & 4 \\
\hline 11 & 5 \\
\hline 13 & 6 \\
\hline 15 & 7 \\
\hline
\end{tabular}

Adapted from Schools for Thought: A Science of Learning for the Classroom, by J. Bruer (Cambridge, MA: MITPress, 1993).

Figure 2

Developmental Aspects of Working Memory 
repeat the name to keep it in working memory. All you have to do is make the association. This kind of rehearsal not only retains information in working memory but also helps move information from working memory to long-term memory.

Teachers need to allocate time for rehearsal during classroom lessons. Teaching too much information too rapidly is likely to be ineffective because, unless students are given time to mentally rehearse each new piece of information, later information is likely to drive it out of their working memories. When teachers stop a lesson to ask students whether they have any questions, they are giving students a few moments to think over and mentally rehearse what they have just learned.

Also, teachers can ask students to verbally repeat key elements of information either as a whole-class response (a technique called Every Pupil Response is discussed later in this article) or through using a cooperative learning technique called Think - Pair - Share. The latter procedure involves having students first rehearse information by themselves, then verbally share key points or ideas with one other student. These kinds of rehearsal activities help students process information in working memory, and thereby establish it in long-term memory.

The limitations of working memory also can be partially overcome by chunking and automaticity. Chunking is the process of combining separate items into large, meaningful units (Miller, 1956). To illustrate, try this simple exercise. Look at the following row of numbers for 5 seconds.

\section{3}

Now cover and try to write down all 24 numbers. How did you do? Most people are unable to remember the list. Now look at the same numbers presented in chunks.

$$
194318672001140012071963
$$

Instead of 24 numbers to remember, you have to remember only six, because the numbers have been "chunked." Chunking requires less working memory space than the individual items of information because you remember the chunked information as a single unit.

Automaticity refers to mental operations that can be performed with little awareness or conscious effort (Schneider \& Shiffrin, 1977). Driving a car is a good example. Once overlearned, people can drive and do other things (listen to the radio, make a telephone call on a cell phone, have a conversation with other people in the car, and so on). As automaticity develops, the time and effort to perform tasks is dramatically reduced (Eggen and Kauchak, 1997). Automaticity can be developed through practice. Sowell (1981) found that "normal" learners require approximately 40 exposures to information before it becomes automatic. Students with mild cognitive disabilities require approximately
200 exposures to information before it becomes automatic.

Students, especially those with cognitive disabilities, have limited space in their working memory. As we teach them, we must remember that they can learn only so much so fast. A mistake that many educators make is to present too much information too quickly. Students' working memories simply can't keep up. Pacing the presentation of information in such a way that students have time to process it all will promote learning and memory. Repeating the same information several times, stopping to write important points on the board or overhead projector, and providing numerous examples and illustrations promote the processing of information in working memory.

The capacity of working memory to accomplish a given learning task differs from one individual to the next. One of the main factors in enhancing this capacity is background knowledge. The more a person knows about something, the better able the person is to organize and absorb new information (Chi \& Ceci, 1987; Engle, Nations, \& Cantor, 1990; Kuhara-Kojima, \& Hatano, 1991).

Prior knowledge is not the only factor. Individuals also differ in their ability to organize information and can be taught to consciously use strategies for making more efficient use of their working memory capacity (Levin \& Levin, 1990; Peverly, 1991; Pressley \& Harris, 1994).

Working memory screens and decides what to do with all the stimuli with which we are bombarded. There are three choices (Eggen \& Kauchak,1997):

1. Disregard the information (purge from memory).

2. Retain the information in working memory by repeating it again and again (rehearsal).

3. Transfer the information into long-term memory through rehearsal or by connecting it with information that is there already (encoding).

Moving information from working memory to long-term memory involves connecting new information with prior knowledge.

\section{Long-Term Memory}

The final component of the human memory system is long-term memory. Long-term memory has three characteristics that are especially worth noting:

1. A long duration

2. An essentially unlimited capacity

3. A rich network of interconnections among the various things stored there.

This component holds information for a relatively long time - a day, a week, a month, a year, or an entire lifetime (Ormrod, 1998). The exact duration of long-term memory has 
never been determined, and perhaps never can be (Eysenck \& Keane, 1990).

Some psychologists believe that information may slowly "weaken" and possibly disappear from long-term memory, especially if it is not used regularly (J. R. Anderson, 1995). Others believe instead that, once information is stored in long-term memory, it remains there permanently but may be extremely difficult to retrieve in some cases (Lofthus \& Lofthus, 1980).

Long-term memory seems to be capable of holding as much information as an individual needs to store there. Theoretically, we should be able to remember as much information as we want for as long as we want. Clark and Paivio (1991) suggested that information is stored in long-term memory as either visual images or verbal units, or both. Other psychologists (Schunk, 1996) believe that many images actually are stored as verbal codes and then translated into visual information when an image is needed. Most cognitive psychologists differentiate three categories of long-term memory: semantic, episodic, and procedural.

\section{Semantic Memory}

Sometimes called declarative memory, semantic memory contains the facts and generalized information that we know; concepts, principles, or rules and how to use them; and problem-solving skills and learning strategies. This memory is mentally organized in networks of connected ideas or relationships called schemata (Voss \& Wiley, 1995). A schema is like an outline, with different concepts or ideas grouped under larger categories. Schemata help us to relate new information to what we already know.

\section{Episodic Memory}

Our memory of personal experiences, is called episodic memory, a mental movie of things we have seen or heard (Slavin, 1997). When you remember what you had for breakfast this morning or what happened at your 12th birthday party, you are recalling information stored in your longterm episodic memory.

Episodic memory also can include flashbulb memory, in which an occurrence of an important event fixes mainly visual and auditory memories in a person's mind. Individuals can remember exactly where they were and what they were doing (even the color of clothes they were wearing) when they heard the news that John F. Kennedy had been assassinated or the news of the Challenger disaster.

Martin (1993) raised an intriguing possibility linking episodic memory and effective instruction. He speculated that educators could improve retention of concepts and information by explicitly creating memorable events involving visual or auditory images through the use of projects, plays, simulations, and other forms of active learning.

\section{Procedural Memory}

Procedural memory is the ability to recall how to do something, especially a physical task. The abilities to drive, type, and ride a bicycle are examples of skills that are retained in procedural memory.

\section{Theories}

Contrary to popular belief, people retain a large portion of what they learn in school (Ormrod, 1998). Long-term retention of information learned in school varies a great deal according to the type of information, however. Concepts usually are retained much longer than names (Conway, Cohen, \& Stanhope, 1991). Retention drops rapidly in the first few weeks after instruction and then levels off (Bahrick $\&$ Hall, 1991). Whatever students have retained about 12 to 24 weeks after instruction, they may retain forever (Slavin, 1997).

Several factors contribute to long-term retention. A major factor is the extent to which students learned the material in the first place (Bahrick \& Hall, 1991). The effects of ability on retention are unclear (Semb \& Ellis, 1994). Higher-ability students score better at the end of a course but often lose the same percentage of what they had learned as low-ability students do. Instructional strategies that involve students actively in lessons contribute to their long-term retention (MacKenzie \& White, 1982). Levels-of-processing theories hold that the more you attend to the details of a stimulus, the more mental processing you must do with a stimulus and the more likely you are to remember it (Bower \& Karlin, 1974).

Clark and Paivio, (1991) proposed a dual-code theory of memory that hypothesizes that information is retained in long-term memory in two forms: visual and verbal (corresponding to episodic and semantic memory, respectively). Their theory predicts that information represented both visually and verbally is recalled better than information represented only one way (e.g. you remember a face better if you also know a name, and you remember a name better if you can connect it to a face).

Bransford et al., (1982) noted that memory does not depend on depth of processing alone but also on the way in which information is learned and then tested. Their transfer-appropriate-processing theory holds that the strength and durability of memory depend not only on the depth of processing but also on the similarity between the conditions under which the material was learned and those under which it is called for. This distinction helps to explain why so many students can recall and apply rules of grammar and punctuation on a multiple-choice or fill-in-theblank test (a format similar to that in which they learned these skills) but are unable to recall or apply the same skills in their own writing. 


\section{INSTRUCTIONAL STRATEGIES DESIGNED TO ENHANCE MEMORY}

Knowing how the brain works in relation to memory is just the beginning for professional educators. Educators want to enhance students' ability to commit important knowledge and skills to memory, to retrieve that same knowledge and skills, and to demonstrate that they have learned the knowledge and skills. Strategies that enhance memory are needed to facilitate a variety of learning goals. For the purposes of this article, five learning goals are identified, and research-based, effective strategies, that align with the learning goals are described. The five learning goals are translated into questions an educator might ask when seeking appropriate strategies. These questions are drawn from our current understanding of how the brain works in relation to memory.

- What strategies facilitate gaining students' attention?

- What strategies facilitate activating students' prior knowledge and experiences?

- What strategies facilitate actively involving students in the learning process?

- What strategies facilitate students' ability to construct meaning?

- What strategies facilitate students' demonstrating their learning?

Although each strategy is included under only one learning question, many strategies can be used throughout the learning process to facilitate various learning goals from increasing attending to helping to construct meaning. The strategies provided are not meant to be exhaustive, nor is the purpose to teach each strategy in-depth or provide illustrative examples for each strategy. The goal is to provide a framework and purpose for strategies that educators currently are using to enhance memory and to allow educators to self-reflect on which strategies they are using and which they might wish to add to their repertoire.

\section{What strategies facilitate gaining and maintaining students' attention?}

Samuel Johnson once said, "The true art of memory is the art of attention" (Klatzky, 1984). Attention means more than students looking at the teacher. It also means focusing one's thinking on the materials at hand for some duration. Anything that captures students' attention and engages their mind has the potential to produce learning. Of course, the opposite is also true: No attention, no engagement, no learning!

Teachers constantly attempt to guide - to gain and maintain - the learners' attention. Attention is a limited resource, allowing us to attend to only one demanding task at a time until that task becomes automatic (L. W. Anderson, 1993). Thus, the first step in learning and remembering important information is to pay attention. Some studies indicate that students can be expected, under the best of circumstances, to be on-task only about three-fourths of the time they are receiving classroom instruction (L. W. Anderson, 1993). Thus, strategies for increasing attention and on-task behavior are important.

Several strategies are effective in focusing students' attention or helping learners pay attention to the "right stuff" or the critical features in the midst of the ever more stimulating learning environment. A variety of techniques can be used to assist students in attending and can increase the amount of time they attend. Some of these strategies facilitate gaining students' attention. The ultimate goal, though, is to help students attend to the material or the content, not just attend to the teacher. These strategies include cues or signals, use of contrast, creating emotion, establishing the purpose for learning and organizing for learning.

\section{Cues or Signals}

Jones and Jones (1990) suggested that a cue or "mand" be taught to alert students to the beginning of a lesson or to signal that critical information is forthcoming. Teachers, then, should provide a signal that tells students to "stop and focus." Cues can be verbal or nonverbal. Verbal cues should be sufficiently engaging and can be generated by the learners, such as "Cool content coming!" or "I need your eyes on the whiteboard at the front of the room". Nonverbal cues could include ringing a bell, playing a musical note, a hand-clap, moving to a certain spot in the room, or even taking off a sports coat. The purpose of the cue is to gain and focus attention quickly. To facilitate implementation of the cue, it must be taught, practiced, and evaluated. After gaining attention, it may have to be regained for individual students or the group as a whole. Moving around the room, walking closer to individual students (proximity), using students' names, and asking students questions can assist in regaining attention.

\section{Use of Contrast}

Learners are bombarded with a variety of information, making it difficult at times to attend to a specific piece of content. Using contrast can assist in arousing attention or refocusing attention. Contrast strategies include:

- altering the physical environment (e.g., changing the arrangement or moving the setting)

- using novelty (e.g., props or jokes)

- changing voice tone, tempo, inflection, accent

- staging an unexpected event

- arousing curiosity through questions

- using movement and sounds 


\section{Creating Emotion}

"Emotions give us a more activated and chemically stimulated brain, which helps us recall things better" (Jensen, 1998). Information that is meaningful to students and contains an emotional "hook" is more likely to be attended to and remembered. Educators portrayed in movies such as the Dead Poet Society and Stand and Deliver illustrate the role of emotion in learning. Of course, extremes of emotions can be counterproductive to attending and learning. Among the strategies that can be used to provide an appropriate level of emotion include:

- storytelling (the educator telling a personal story aligned with the learning or learners creating personal stories aligned with the learning, allowing the learner to relate the learning to family, neighborhood, city, life, etc.)

- centering the learning on a celebration

- establishing a controversy through debate, dialogue, role-played argument

- using a game format, music, or drama

- using tangible artifacts or pictures that allow learners to visually connect to the learning

- teacher modeling enthusiasm for the learning activity

In addition to these specific strategies, brain research clearly indicates that an appropriate, strongly positive climate is needed to assist learners in attending to learning. Relationship building, providing a rich environment, and eliminating threats are all needed to create the type of "emotional climate" necessary for students to attend to learning. Emotion is not only a powerful tool for gaining and maintaining learners' attention; it also is an excellent tool to conclude the learning experience. Engaging emotions immediately after a learning experience increases the likelihood that the memories will be recalled, and recalled more accurately (McGaugh et al., 1995).

\section{Establishing Purpose for Learning}

How often has the learner asked you, "Why are we learning this?" or "When will I ever use this?" When students are clear about the purpose for learning a piece of knowledge or skill, their attention to the learning increases. Strategies that can enhance establishing the purpose for learning include:

- The educator states the purpose for the learning (goals and objectives), which the learner then restates.

- Both educator and learner generate future uses of the learning.

- The student has choices in the learning, including choice in content, timing, work partners, projects, process, environment, or resources.
- The educator and the learner generate questions prior to the learning (e.g., Why is this material important? How will you study the material? What strategies will you use?)

- Learners predict what might happen in the learning (e.g., What do you think would happen if. ...?)

- Learners establish personal goals related to the learning and communicate why attaining these goals is important to them. In this personal goal-setting process, encouragement and feedback are crucial.

\section{Organizing for Learning}

Attention can be facilitated if the learner previews what is about to be learned and understands the big picture or the "gist" of the total learning that is about to take place and where that learning "fits. "Wholes taught before parts are recalled better" (Jensen, 1998). Advance organizer strategies, which present information prior to learning in a variety of forms, are powerful tools for focusing attention. They also increase the likelihood of the learner understanding the new learning. People learn "by organizing new information into hierarchies and organizing information so that the relationships between isolated bits of information can be detected. Faw and Waller (1976) indicate that advance organizers are "a kind of conceptual bridge between new material and students' current knowledge," making them an excellent technique for linking prior knowledge to new learning, as well as for organizing learning.

Research on advance organizers indicates they help learners learn if students can see the relationships among key concepts, terms, concept illustrations, and details (Mayer, 1984; Dinnell \& Glover, 1985; Corkill, 1992). In addition, learners must be able to paraphrase the organizer in their own words or the advance organizer is not meaningful to the new learning.

Among the various types of advance organizers are diagrams, analogies, and concrete models. Several advance organizer techniques are available from the University of Kansas (Deshler \& Schumaker, 1992). These strategies include the Survey Routine, the Lesson Organizer, the Unit Organizer, and the Course Organizer. These organizers help create an outline or a map in which pieces of information can be organized. A sample advance organizer designed to assist the learner in organizing for learning is featured in Figure 3.

As we leave the area of strategies designed to gain and maintain attention to facilitate learning and memory, we would be remiss in not stating that techniques to facilitate attending must be used in the context of "attending to what." As professional educators, knowing the limitation of attention and memory, we must ensure that what we are asking students to attend to is worthy of attention. That requires a 


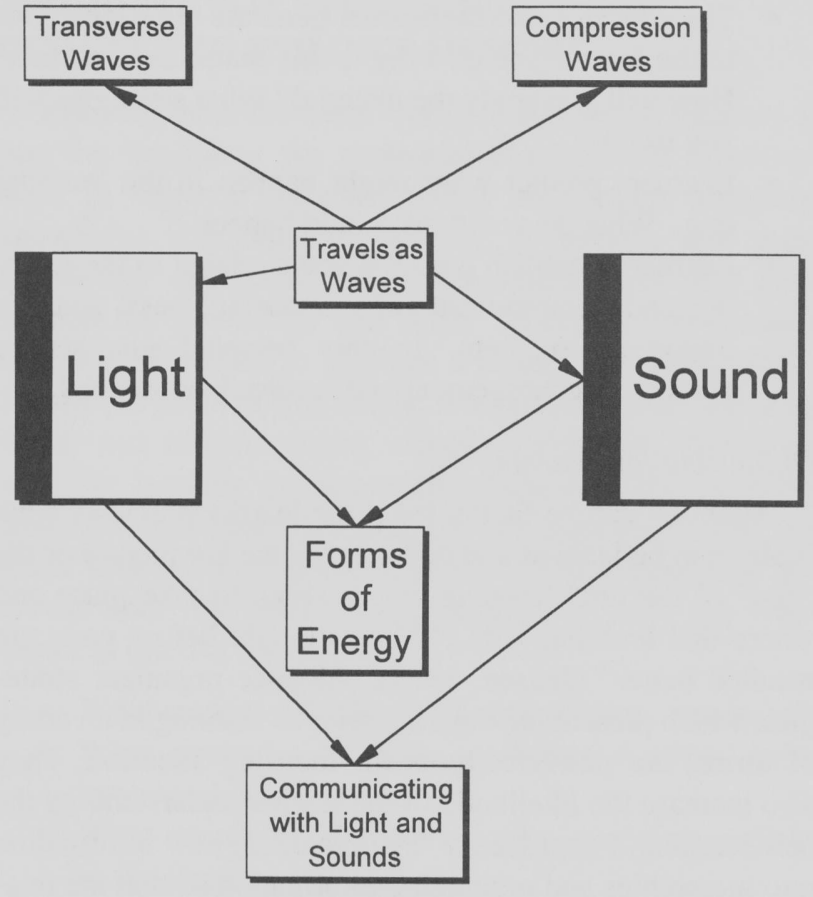

Figure 3

Sample Advance Organizer

constant evaluation: "Is this a "need to know" or a "nice to know" piece of learning?

\section{What strategies facilitate activating students' prior knowledge and experiences?}

"Knowledge is more than the end product of previous learning; it also guides new learning" (Woolfolk, 1998, p. 247). The research is clear on the role of prior knowledge as it relates to memory and learning. Having prior knowledge or experience which relates to the current learning enhances memory and conversely, lacking prior knowledge or experience with the current learning reduces memory. "What we already know determines to a great extent what we will pay attention to, perceive, learn, remember, and forget" (Woolfolk, 1998, p. 247).

Educators have two choices.

1. They can find the knowledge and experience the student currently has and "hook" the new learning to it. Our goal is to help students recall what they know about a topic and help them use this knowledge gained previously to guide their comprehension of the new learning.

2. If no prior knowledge or experience exists or cannot be tapped, educators can create the prior experience.
Either way, several specific strategies can assist educators to connect new learning to prior knowledge and experience:

- Brainstorming or sharing. Though a simple strategy, a powerful strategy can be to have learners brainstorm or share what knowledge or experience they bring to the learning that might relate to the current learning.

- A KWL graphic organizer developed by Ogle (1989). The KWL strategy allows the learner to bring to the surface prior knowledge by generating what is known about a topic. This can be done individually or in a group. After generating what is known, learners generate what they want to know-which is an excellent way to establish a purpose for learning. After learning, students generate what they have learned-an excellent way to compare prior knowledge which might have been erroneous, with new, accurate knowledge. Figure 4 provides an illustrative example of a KWL graphic organizer.

- An anticipation guide, sometimes called a prediction guide. Designed to activate students' prior knowledge about a topic and provide purpose for future learning before they engage in reading or in some other form of acquiring new information, these guides help prepare learners by asking them to react to a series of statements related to the content of the new learning. Readance, Bean, and Baldwin (1995) described the basic steps for constructing an anticipation guide and have provided numerous examples. Figure 5 gives an example of an anticipation guide.

- PreP teaching technique. This prereading technique, developed by Langer (1981 \& 1982) allows students in a group discussion an opportunity to generate what they know about a topic ("What comes to mind when...."), to reflect on their initial associations ("What made you think of ...."), and to reformulate their ideas ("Have you any new ideas about...?"). Langer stated, "When preparing students for a reading activity, we can help them become aware of relevant prior knowledge, while we judge whether or not that knowledge is sufficient for comprehension of the text. At that point we will be able to make knowledgeable decisions about reading assignments and instruction" (p. 153). This technique can be modified slightly to generate and evaluate students' prior knowledge in preparation for other information-acquiring activities besides reading, such as an activity, a lecture, or other forms of learning (Wollen \& Lowery, 1974).

- Metaphors, analogies, imagery. These are powerful strategies that allow prior knowledge of something to influence the learning of something new. Imagery, for example, is based on the knowledge that the brain has 
Topic of Study:

\begin{tabular}{|c|c|c|}
\hline What We know & What We want to know & What We learned \\
\hline $\begin{array}{l}\text { Examples: newts, toads } \\
\text { Habitat: Live near water }\end{array}$ & $\begin{array}{l}\text { Where they came from } \\
\text { Variance in size } \\
\text { How they reproduce }\end{array}$ & $\begin{array}{l}\text { Came from: First vertebrate } \\
\text { to walk on land. Evolved } \\
\text { from lobe-finned fishes } \\
350 \text { million years ago. } \\
\text { Reproduce: Lay eggs in } \\
\text { water or in moist environments. } \\
\text { Eggs are not watertight. }\end{array}$ \\
\hline
\end{tabular}

Figure 4

K-W-L Graphic Organizer

an amazing ability to construct and retain images. Following the old adage, "A picture is worth a thousand words," educators might provide images, a strategy that is best for young children (called imposed images), whereas older students tend to gain more from images they create themselves (called induced imagery).

\section{Math Class}

Name:

Directions: With your learning partner, read and discuss the statements below. Check whether you agree or disagree. Be able to support your answer with an example.

1. Multiplication is just like addition, only faster. We agree $\square$ We disagree $\square$ Because . . .

2. When multiplying 0 times any number, it always ends up 0 .

We agree $\square$ We disagree $\square$ Because . . .

3. When multiplying two-digit numbers by twodigit numbers, you start on the left.

We agree $\square$ We disagree $\square$ Because . . .

4. Multiplication "facts" should be memorized because this saves you time.

We agree $\square$ We disagree $\square$ Because . . .

5. Multiplication never will be used outside of math class.

We agree $\square$ We disagree $\square$ Because . . .
Creating prior knowledge or an experience can be as simple as bringing an object to the lesson to a hands-on learning activity to a field trip. The goal is to allow learners to have an experience to which they can "tie" the new learning.

\section{What strategies facilitate actively involving students in the learning process?}

The saying "learning is not a spectator sport" is founded in a large body of research confirming that active engagement enhances memory and learning. Reflecting on yourself as a learner should confirm this fact. Bloom (1987) offered the following regarding engaging individuals actively in learning. Learners will retain:

$10 \%$ of what they READ

$20 \%$ of what they HEAR

$30 \%$ of what they SEE

$50 \%$ of what they SEE \& HEAR

$70 \%$ of what they SAY

$90 \%$ of what they SAY \& DO.

Among the strategies that enhance memory through active learning are:

- Every pupil response (EPR). EPR techniques allow learners, individually, in small groups, or even in large groups, to illustrate their learning. A variety of techniques can be used to elicit an EPR. Examples include finger signals, small individual chalkboards or white erase boards, and cards (such as true/false, yes/no, add/subtract). With EPR techniques, all students are involved, in contrast to the method of calling on one student at a time for response. EPR responses allow educators to determine what students have learned and possible areas for reteaching. In addition, learners receive immediate feedback on their learning.

Figure 5 Sample Anticipation Guide
- Cooperative learning. Certainly cooperative learning is one of the most research-based techniques for 
actively involving all students in the learning process (Slavin, 1991). Whether using the Johnson and Johnson (1994) approach, the Slavin approach (1995), the Kagan approach (1992), or others, cooperative learning allows for equal participation, simultaneous interaction, and individual and group accountability. A plethora of resources is available on cooperative learning.

- Reciprocal teaching/learning. This instructional strategy is effective in activating learners and assisting both below-level readers and learners struggling with content (Palincsar, 1984; Palincsar \& Brown, 1986; Snow, Burns, \& Griffen, 1998). Reciprocal teaching uses four additional strategies: summarizing, asking questions, making predictions, and clarifying. The teacher and students take turns being the teacher, modeling the use of the strategies. Reciprocal teaching/learning is also an excellent strategy for constructing meaning.

- Simulations/role playing/debates/projects. These techniques afford students the opportunity to engage in "real life" experiences and provide for "hands-on" experiences. Projects, for example, are a rich source of active learning, providing opportunities for motivating the learner, as well as integrating across disciplines and requiring students to demonstrate a variety of skills. Simulations and role playing involve students' entire physical self. Debates encourage students to explore and understand a topic or concept from multiple perspectives.

- Hands-on learning using models and/or manipulatives. Two content areas, science and mathematics, are prime areas for utilizing hands-on learning techniques, regardless of grade level or age. The science and math education literature provide extensive documentation that learning with models and manipulatives increases active involvement and also meaning and understanding. The approach of using manipulatives and hands-on learning for both science and mathematics is supported by the U.S. Department of Education's Guidebook to Examine School Curricula (1997), based on the Third International Mathematics and Science Study (TIMSS Report) (1998).

Educators must continually evaluate the teaching/learning process, asking the question, "Who is interacting more with the content-the teacher or the student?" Once again, these techniques must be evaluated within the context of what knowledge or skill the learner is being asked to experience through active learning. Is the learning important and relevant? Even if students are actively engaged, if the learning is not relevant and has no future use, the value of the active learning experiences must be questioned.

\section{What strategies facilitate students' ability to construct meaning?}

Minds tend to remember content that is meaningful, as well as structured (Jensen, 1998). The educator's goal, then, is to assist learners in constructing meaning. Certainly the strategies indicated in the prior-knowledge discussion apply to constructing meaning. A number of additional techniques also are available to assist in the learning and memory process.

- Graphic organizers. Graphic organizers concretely represent abstract or implicit information, show relationships, help to organize ideas, help to relate new information with prior knowledge, and assist in the storage and retrieval of information. They are effective in helping learners construct meaning (Heimlich \& Pittelman, 1986; Pehrsson \& Robinson, 1985) by visually representing the meaning they construct from reading or listening. Many types of graphic organizers are available to the teacher and the learner, including semantic maps, story maps, Venn diagrams, character description maps, and cause/effect diagrams (Figure 6).

Excellent resources for graphic organizers have been developed by Hyerle (1996), Parks and Black (1990), Richardson and Morgan (1994), Jensen (1998), and Billmeyer (1995). Even though many graphic organizers can help students visually construct meaning, research on upper-grade intervention has shown that it is most effective to use one graphic organizer per text (Cooper et al., (1997).

In teaching students how to use and independently implement graphic organizers, the educator should discuss the benefits, introduce the purpose and specific form, apply the organizer to familiar and then new material, and allow students an opportunity to reflect on use of the graphic organizer. Once mastered, many opportunities should be provided for students to independently select the appropriate graphic organizer, matching the organizer selected to the learning need. In addition, students should have opportunities to construct their own graphic organizers.

- Comprehension-monitoring strategies. Comprehension-monitoring strategies are particularly useful during reading. Effective readers apply comprehensionmonitoring strategies as a means of critically interacting with the text throughout the reading process and constantly being aware of their own thinking (Barr, Kamil, Mosenthal, \& Pearson, 1991; Winograd \& Paris, 1989). A variety of strategies, such as selective underlining, anticipation guides (Readence, Bean, \& Baldwin, 1995), study guide completion, self-questioning, two-column notes (Project 
Unit FRAME

Key Topic:

Basketball

\begin{tabular}{l|l|l|}
\hline $\begin{array}{l}\text { Main Idea } \\
\text { On balance }\end{array}$ & $\begin{array}{l}\text { Main Idea } \\
\text { Technique \& Form }\end{array}$ & Main Idea \\
& & Rules \\
\hline Feet wide apart & Back rotation of ball & Number on court \\
\hline $\begin{array}{l}\text { One foot slightly in front of } \\
\text { other } \\
\text { Hips and shoulders over foot }\end{array}$ & Guide hand side of ball & Travelling \\
\hline
\end{tabular}

The Frame Routine (The Big Picture)

E. S. Ellis, University of Kansas, 1997
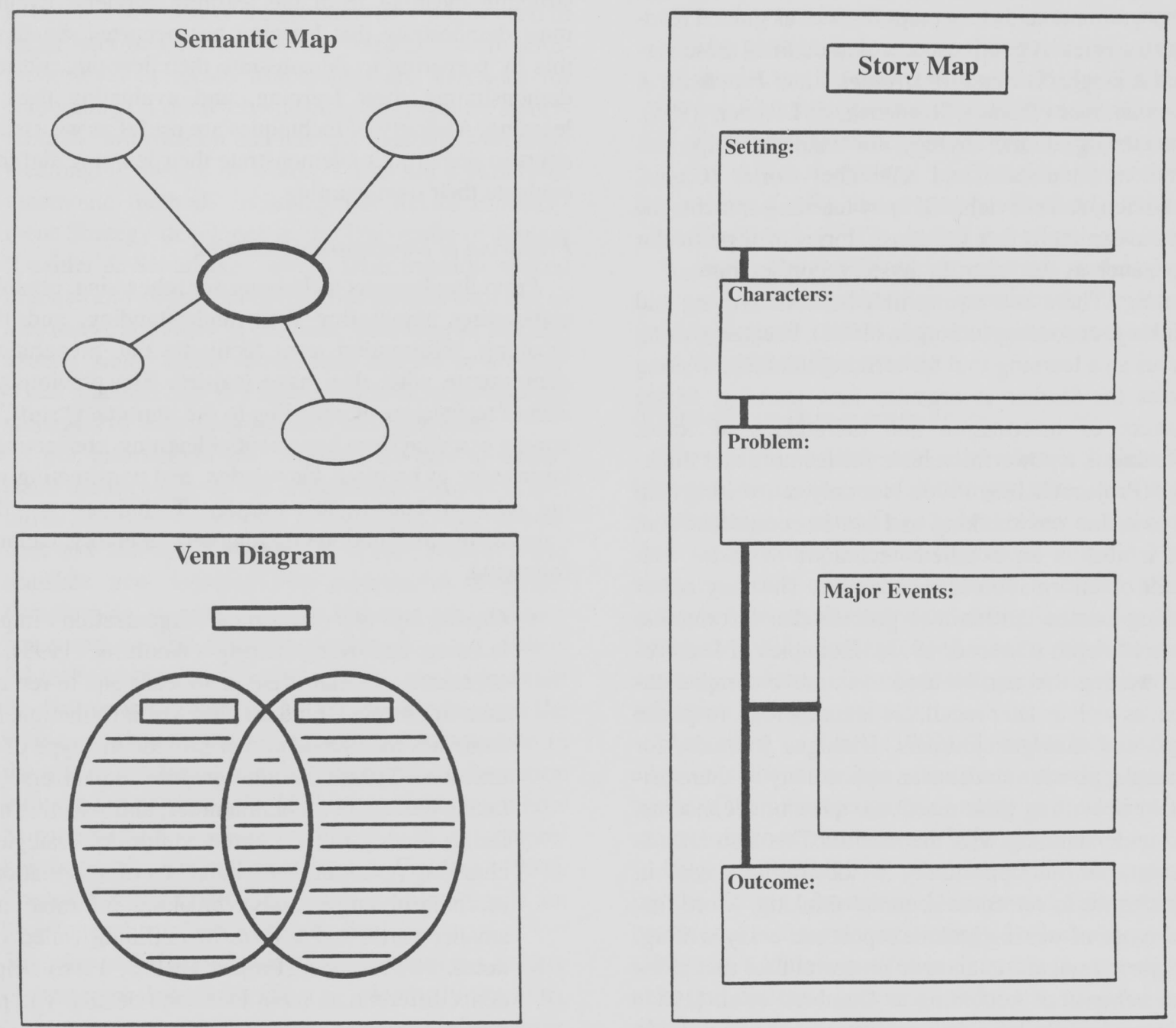

Figure 6

Sample Graphic Organizers 
CRISS, 1996), induced imagery, GIST(Cunningham, 1982), and the ReQuest procedures (Manzo, 1985) are all designed to teach the learner how to monitor their comprehension throughout the reading and learning process. GIST, for example, provides students with a format for generating the "gist" or summary of a reading passage, which progresses from a teacher-directed strategy to one that the student applies independently.

- Understanding text structure. Students' knowledge of text structure plays an important role in comprehension, according to Barr, Kamil, Mosenthal, and Pearson (1991). Various strategies are available to assist learners in understanding text structure. Selective underlining/highlighting and power notes are two strategies developed through Project CRISS (1996). Additional strategies include graphic organizers, study guides, idea mapping, the text structure strategy, story grammar and story maps, as well as guided reading strategies. A good resource that outlines these various strategies is Reading Strategies and Practices: A Compendium (Tierney, Readence, \& Dishner, 1995). The story grammar strategy, for example, helps students to understand and remember stories (Gagne, Yekovich, \& Yekovich, 1993) by teaching students the typical structure that fits most stories of a particular type, such as the "murder mystery story grammar."

- Writing. There is a strong link between writing and thinking, according to Sorgen (1998), because writing serves as a learning tool for refining thinking. Writing forces the learner to organize new learning, to see clusters of information and hierarchies of ideas. "Writing is a powerful vehicle for learning and thinking" (Project CRISS, 1996). Not only can writing help us to refine our thinking and aid in comprehension, but it also is an excellent technique to assist with recall of information at a later time. The very act of writing causes the brain to process that information more in-depth (Ormrod, 1998). Examples of less formal writing that can be used to improve comprehension, as well as later recall, are learning logs, response $\operatorname{logs}$, and dialogue journals. Dialogue journals, for example, provide students an opportunity to share privately in writing their reactions, questions, concerns, and understanding with the teacher. This also affords the teacher an opportunity to determine errors in thinking or to reinforce accurate thinking. More formal types of writing include report and essay writing.

- Imagery. Imagery is another powerful tool that aides comprehension. According to Gambrell et al. (1987) "Mental images have two great values: They provide a framework for organizing and remembering information from text, and when students induce images, they expand more energy for integrating information across text. Benefits occur in both comprehension and recall" (p. 639).

- Drawing/lllustrating. The old saying, "A picture is worth a thousand words" probably could be modified slightly based on recent brain research, "A picture improves memory by a thousand-fold." Drawings and illustrations can be applied to learning vocabulary or depicting concepts and content. An example provided by Sorgen (1998) includes using parts of the body to illustrate the relationship of different units of weight.

\section{What strategies facilitate students' demonstrating their learning?}

After attending to learning, attaching new learning to prior knowledge, actively engaging in the learning, and constructing meaning from the learning, students eventually must demonstrate that learning has occurred. Students do this by preparing to demonstrate their learning, ultimately demonstrating their learning, and evaluating their own learning. A variety of techniques are useful as we assist students in preparing to demonstrate their learning and then to evaluate their own learning.

\section{Preparing to Demonstrate Learning}

Providing learners techniques for rehearsing, organizing, elaborating, monitoring their understanding, and finally recalling information can facilitate the preparation to demonstrate what they have learned. The previously discussed techniques of attending to the important "stuff," separating essential from nonessential learning, connecting new knowledge to previous knowledge, and constructing meaning all contribute to this transfer. Techniques specific to transferring information into long-term memory, include the following.

- Organizing the material. Organization improves learning and remembering (Woolfolk, 1998). Well organized material is easier to learn and to remember than fragmented, random pieces of information. Many strategies mentioned earlier provide this type of organization. These include graphic organizers, notetaking guides, two-column notes, and selective underlining, among others. Three additional strategies are chunking (grouping individual bits of information into meaningful larger units), breaking information into smaller parts, and a form of outlining called power notes. Power notes (Project CRISS, 1996) help students differentiate main ideas and details. The procedure is similar to outlining but is easier because of the method of assigning numbers. This tool can be used for reading, writing, and studying. 
- Rehearsing. Once the information is organized, several strategies can aid the learner in committing that information to memory. At times learners are asked to rote-memorize information, which requires the learner to repeat the information in various ways but does not necessarily require the learner to understand the meaning of the information. Though rote memorization has its role in the classroom, the focus is primarily on committing to memory information that has meaning. Again, a number of the strategies mentioned earlier can be used for both rote and meaningful memorization, including imagery.

Several additional strategies particularly useful for rote memorization include mnemonics, spatial visualization, rhymes, repeating, and copying. These strategies must be applied through repetitive and distributive practice. Mnemonics for example, allow learners to commit to memory information they might need to recall later or information they need at a more automatic level of recall. Mnemonics are strategies for elaborating on relatively meaningless input by associating the information that has less meaning with more meaningful images or words. There are a variety of mnemonic methods including the Recall Enhancement Strategy developed at the University of Kansas (Deshler \& Schumaker, 1992). Distributed or spaced practice allows practicing for brief periods with rest or alternative activities in between. This type of practice usually yields better results than massed or concentrated practice. The key is to provide students specific strategies to help them practice and remember.

For information that requires learners to understand the meaning of the information, various elaboration strategies are critical in helping learners to connect new learning with what is already familiar or to translate new learning into meaningful language. Paraphrasing, summarizing, creating analogies, answering questions, and describing connections are powerful techniques to help learners learn new information on their own. Summarizing, for example, requires the learner to identify the most important information in the text or the lesson and to integrate this information into a meaningful whole. Helping students learn how to summarize has a positive effect both on comprehension and on recall (Pearson \& Fielding, 1991). Project CRISS (1996) provides specific details on how to teach students to summarize.

- Studying techniques. Students need access to a variety of strategies that enable them to selectively attend to, review, and commit to memory pertinent information. Many strategies previously discussed can assist learners in studying. These include graphic organizers such as KWL, two-column notes, and mnemonic strategies. Studying is aided greatly if the learner knows what is important. Educators can assist students with this by establishing specific criteria, standards, and expectations for the learning. Rubrics or scoring guides are an excellent tool to help accomplish this up-front establishment of expectations: "Scoring criteria make public what is being judged and, in many cases, the standards for acceptable performance," according to Herman, Aschbacher, and Winters (1992, p. 44). In addition, scoring guides provide students with specific feedback to contribute to improved performance.

Students' ability to demonstrate their learning is also greatly aided by teaching students how to take tests. Woolfolk (1998) referred to research demonstrating that students' test-taking skills are enhanced through direct experience with the format of the test, as well as training in general cognitive skills such as solving problems, analyzing questions, being attuned to details, and checking one's work. Project CRISS (1996) provides strategies for increasing students' proficiency in test taking, such as predicting test questions.

Another strategy is Question-Answer Relationships (QAR), developed by Raphael (1982), which Simmonds (1992) studied for effectiveness with students. The QAR strategy enhances students' ability to answer comprehension questions by giving them a systematic means for analyzing questions prior to answering the question.

\section{Evaluating one's own learning}

The ability to learn and remember is influenced by a learner's metacognitive skill. Simply stated, this is the ability to reflect on yourself as a learner: How do I plan to learn? How do I monitor my learning? How well did I do? Do I need to make changes? There is a direct relationship between metacognition and the ability to transfer (Perkins \& Salomon (1992). Students need time to self-reflect and selfevaluate, and they also need strategies to facilitate this selfreflection and self-evaluation.

According to Barell (1992) "In order to transfer knowledge or skills from one situation to another, we must be aware of them; metacognitive strategies are designed to help students become more aware." (p. 259).

Project CRISS (1996) provides several strategies including the Strategy Inventory. Deshler and Schumaker (1992) provided a self-regulating strategy for learners called I-Can (1992). In addition, portfolios, learning logs, response journals, and dialogue journals-as long as they are accompanied by criteria for judging work-are all tools to assist with the self-reflection and self-evaluation process (Johnson \& Rose, 1997). 


\section{WHY DO WE FORGET?}

Why do we remember some things and forget others? Why can we sometimes remember trivial things that happened years ago but not important things that happened yesterday? Most forgetting occurs because information in working memory was never transferred to long-term memory (Slavin, 1997). It also can occur because we lose our ability to recall information in long-term memory. Over the past few decades, researchers have identified several factors that make it easier or more difficult to remember information. Several key factors that can make it difficult to recall important information are failure to store, failure to retrieve, time decay, interference/inhibition, primacy and recency effects, insufficient practice, and exceptionality.

People fail to store information when it does not reach long-term memory to begin with (Eggen \& Kauchak, 1997). Perhaps an individual receiving a piece of information didn't pay attention to it, so it didn't go beyond the sensoryregister stage of processing information. Or perhaps the individual, after attending, didn't process the information beyond the working-memory stage. Teachers have to continually focus students' attention on important information to be learned and engage them in actively rehearsing that information until the students securely retain it in long-term memory.

Failure to retrieve occurs when we can't locate information stored in long-term memory because we learned the information at a rote level or did not have sufficient retrieval cues to point the long-term memory search in the right direction. Almost everyone has had the experience of taking a test, coming upon a test question we know we know the answer to, but just not retrieving the correct response during the allotted time for the test. This sometimes is referred to as the "tip-of-the-tongue-phenomenon" (Brown \& McNeill, 1966). Students are more likely to retrieve information when they have associated it with many other things in their existing knowledge base. The more interrelationships students form among pieces of information in long-term memory, the more easily they can retrieve those pieces later on.

Also, the more time that passes after learning, the less will be remembered. This form of forgetting is often referred to as "time decay" (Woolfolk, 1998). Neural connections, like muscles, grow weak without use. Frequent reviews and tests, elaborated feedback, and active involvement of students in learning projects all have been associated with longer retention.

Interference (also called inhibition) occurs when information gets mixed up with, or pushed aside by, other information. Retroactive interference/inhibition is especially likely when pieces of information are similar to one another (e.g., young students might have difficulty clearly distinguishing the letter $\mathrm{b}$ from the letter $\mathrm{d}$ if both are taught within a similar timeframe).

When proactive interference/inhibition occurs, learning one set of information interferes with learning later information (e.g., in the United States we learn to drive on the righthand side of the road. Many of us become confused when we travel to England and have to drive on the left side of the road). Teaching students to use varied rehearsal strategies-such as visualization, overt rehearsal (saying information aloud), covert rehearsal (saying information to oneself), writing the information, or combination approaches-could prevent interference/inhibition from affecting the memory process.

When given a list of words to learn, then tested immediately afterward, people tend to learn the first few words (primacy effect) and the last few items (recency effect) much better than those in the middle of the list (Stigler, 1978). We pay more attention and devote more mental effort to items presented first and last.

Insufficient practice also can negatively impact memory. The most common method for committing information to memory is also the most mundane: practice. Distributed practice (a little each day over time) allows for better retention, especially when factual learning is involved (Dempster, 1991). Cramming the night before a test might get you through the test, but you probably won't integrate the information well into your long-term memory.

Various learning disorders and exceptionalities also can have an impact on the memory process. Students with learning disabilities often have difficulty with specific memory storage processes (Mastropieri \& Scruggs, 1990; Torgesen, Wagner, Simmons, \& Loughon, 1990; Cornoldi, 1990; McDaniel, Einstein, \& Waddill, 1990). These students often take a passive approach to learning rather than actively involving themselves in a learning task (Ormrod, 1998). They might have a smaller working memory capacity and be less likely to use processes such as meaningful learning, organization, and elaboration. Students with mental retardation typically process information more slowly; and students with behavioral disorders tend to have difficulty keeping their attention on the task at hand (Turnbull, Turnbull, Shank, \& Leal, 1995). In contrast, students who are gifted are likely to process information more rapidly and in a more complex manner than many of their classmates (Heward, 1996)

Virtually all students, those with and without exceptionalities, will have difficulty learning or remembering classroom material at times. All students stand to benefit from instructional strategies that will assist them to process information more effectively. 


\section{SIX FINAL TIPS}

Woolfolk (1998, p. 265) suggested six practical guidelines for promoting memory in the classroom:

1. Make sure you have students' attention.

2. Help students separate essential from nonessential details and focus on the most important.

3. Help students connect new information with what they know already.

4. Provide for repetition and review of information.

5. Present material in a clear, organized way.

6. Focus on meaning, not memorization.

\section{CONCLUSION}

The ultimate goal of teaching techniques for enhancing memory is to allow students to control their learning. Enhancing memory requires students to:

- know how to focus their attention and on what

- know how to connect new learning to prior knowledge

- know how to engage themselves actively in learning so they are able to create and construct their own learning

- know how to commit information to memory, how to retrieve information, and how to demonstrate their learning of new concepts and skills across a variety of situations

The goal is to create independent learners. The old adage, "Give me a fish, and I can eat for a day. Teach me to fish, and I can eat for a lifetime" summarizes the intent of teaching memory-enhancing techniques. Wolfe (1998) put it this way, "Better learning will come not so much from finding better ways for the teacher to instruct, but from giving the learner better opportunities to construct their learning" (p. 3).

\section{REFERENCES}

Anderson, J. R. (1995). Cognitive psychology and its implications (4th ed.). New York: Freeman.

Anderson, L. W. (1993). What time tells us. Timepiece: Extending and enhancing learning time, National Association of Secondary School Principals.

Atkinson, R. C., \& Shiffrin, R. M. (1968). Human memory: A proposed system and its component processes. In K. Spence \& J. Spence (Eds.), The psychology of learning and motivation (Vol. 2). New York: Academic Press.

Bahrick, H. P., \& Hall, L. K. (1991). Lifetime maintenance of high school mathematics. Journal of Experimental Psychology, 120, 20-23.

Barell, J. (1992). Like an incredibly hard algebra problem: Teaching for metacognition. In A. L. Costa, J. A. Bellanca, \& R. Fogarty (Eds.), If minds matter: A forward to the future (Vol. 1). Palatine, IL: IRI/Skylight Publishing.

Barr, R., Kamil, M. L., Mosenthal, P. B., and Pearson, P. D. (1991). Handbook of reading research (Vol. 2). New York: Longman.

Billmeyer, R., (1995). Teaching reading in the content areas: If not me, then who? Colorado: McREL Institute.
Bloom, B. (1987). The closing of the American mind. New York: Simon \& Schuster.

Bower, G. H., \& Karlin, M. B. (1974). Depth of processing pictures of faces and recognition memory. Journal of Experimental Psychology, 103, $751-757$.

Bransford, J. D., Stein, B. S., Vye, N. J., Franks, J. J., Auble, P. M., Mezynski, K. J., \& Pefertto G. A. (1982). Differences in approaches to learning: An overview. Journal of Experimental Psychology: General, 3, 390-398.

Brown, R., \& McNeill, D. (1966). The "tip-of-the-tongue" phenomenon. Journal of Verbal Learning \& Verbal Behavior, 5, 325-337.

Bruer, J. (1993). Schools for thought: A science of learning for the classroom. Cambridge: MIT Press.

Caine, G. \& Caine, R. N. (1997). Education on the edge of possibility. Alexandria, VA: Association for Supervision and Curriculum Development.

Chi, M. T. H., \& Ceci, S. (1987). Content knowledge: Its role, representation, and restructuring in memory development. In H. W. Reese (Ed.), Advances in child development and behavior. Orlando: Academic Press.

Clark, J. M., \& Paivio, A. (1991). Dual coding theory and education. Educational Psychology Review, 3(3), 149-210.

Conway, M. A., Cohen, G., \& Stanhope, N. (1991). Very long-term memory of knowledge acquired through formal education: Twelve years of cognitive psychology. Journal of Experimental Psychology: General, 120, 395-409.

Cooper, J. D., Boschken, I., McWilliams, J., \& Pistochini, L. (1997). A study of the effectiveness of an intervention program designed to accelerate reading for struggling readers in upper grades. Unpublished final report.

Corkill, A. J. (1992) Advance organizers: Facilitators of recall. Educational Psychology Review, 4, 33-67.

Cornoldi, C. (1990). Metacognitive control processes and memory deficits in poor comprehenders. Learning Disability Quarterly, 13(4), 245-257.

Craik, F. I. M., \& Lockhart, R. S. (1972). Levels of processing: A framework for memory research. Journal of Verbal Thinking \& Verbal Behavior, 11, 671-684.

Cunningham, J. W. (1982). Generating interactions between schemata and text. In Niles, J. A. \& Harris, L. A. (Eds.), New inquiries in reading research and instruction. Washington, DC: National Reading conference.

Dempster, F. (1991). Synthesis of research on reviews and tests. Educational Leadership, 48(7), 71-76.

Deshler, D. D. \& Schumaker, J. B. (1992). Content enhancement series and learning strategies. Lawrence, KS: University of Kansas, Center for Research on Learning.

Dinnell, D., \& Glover, J. A. (1985). Advance organizers: Encoding manipulations. Journal of Educational Psychology, 77, 514-522.

Eggen, P., \& Kauchak, D. (1997). Windows on classrooms: Educational psychology (3d ed.). Columbus, $\mathrm{OH}$ : Merrill-Prentice Hall.

Ellis, E. S. The frame routine. Lawrence: University of Kansas.

Engle, R. W., Nations, J. K., \& Cantor, J. (1990). Is "working memory capacity" just another name for word knowledge? Journal of Educational Psychology, 82(4), 799-804.

Ericcson, K. A., \& Kintsch, W. (1995). Long-term working memory. Psychological Review, 102, 211-245.

Eysenck, M. W., \& Keane, M. T. (1990). Cognitive psychology: A student's handbook. Hove, UK: Erlbaum.

Faw, H. W., \& Waller, T. G. (1976). Mathemagenic behaviors and efficiency in learning from prose. Review of Educational Research, 46, 691-720.

Gagne, E. D., Yekovich, C. W., \& Yekovich, F. R. (1993). The cognitive psychology of school learning (2d ed.). New York: HarperCollins.

Gambrell, L. B., Kapinus, A., \& Wilson, R. M. (1987). Using mental imagery and summarization to achieve independence in comprehension. Journal of Reading, 30, 638-642.

Heimlich, J. E., \& Pittelman, S. D. (1986). Semantic mapping: Classroom applications. Newark, DE: International Reading Association.

Henson, K. T., \& Eller, B. F. (1999). Educational psychology for effective teaching. Albany, NY: Wadsworth.

Herman, J. L., Aschbacher, P. R., \& Winters, L. (1992). A practical guide to alternative assessment. Alexandria, VA: Association for Supervision and Curriculum Development.

Heward, W. (1996). Exceptional children (5th ed.). Upper Saddle River, NJ: Merrill/Prentice Hall.

Hyerle, D. (1996). Visual tools for constructing knowledge. Alexandria, VA.: Association for Supervision and Curriculum Development.

Jensen, E. (1998). Teaching with the brain in mind. Alexandria, VA: Association for Supervision \& Curriculum Development. 
Johnson, D., \& Johnson, R. (1994). Learning together and alone: Cooperation, competition, and individualization (4th ed.). Boston: Allyn \& Bacon.

Johnson, N. J., and Rose, L. M. (1997). Portfolios: Clarifying, constructing, and enhancing. Lancaster, PA: Technomic Publishing.

Jones, V. F., \& Jones, L. S. (1990). Comprehensive classroom management: Motivating and managing students ( $3 \mathrm{~d}$ ed.). Needham Heights, MA: Allyn \& Bacon.

Kagan, S. (1992). Cooperative learning. San Juan Capistrano, CA: Kagan Cooperative Learning Company.

Klatzky, R. (1984). Memory and awareness. New York: Freeman.

Kuhara-Kojima, K., \& Hatano, G. (1991). Contribution of content knowledge and learning ability to the learning of facts. Journal of Educational Psychology, 83 (2), 253-263.

Langer, J. A. (1981). From theory to practice: A prereading plan. Journal of Reading, 25, 152-156.

Langer, J. A. (1982). Facilitating text processing: The elaboration of prior knowledge. J. Langer \& M. Smith-Burke (Eds.), Reader meets author: Bridging the gap. Newark, DE: International Reading Association.

Levin, M. E., \& Levin, J. R. (1990). Scientific mnemonics: Methods for maximizing more than memory. American Educational Research Journal, 27, 301-321.

Lofthus, E. F., \& Lofthus, G. R. (1980). On the permanence of stored information in the human brain. American Psychologist, 35, 409-420.

MacKenzie, A. A., \& White, R. T. (1982). Fieldwork in geography and long-term memory. American Educational Research Journal, 19 $623-632$.

Manzo, R. (1985). Expansion models for the ReQuest, CAT, GRP, and REAP reading/study procedures. Journal of Reading, 28, 498-503.

Martin, J. (1993). Episodic memory: A neglected phenomenon in the psychology of education. Educational Psychologist, 28(2), 169-183.

Massaro, D. W., \& Cowan, N. (1993). Information processing models: Microscopes of the mind. Annual Review of Psychology, 44, 383-425.

Mastropieri, M., \& Scruggs, T. (1990). Memory and learning disabilities. Learning Disability Quarterly, 13(4), 234-235.

Matlin, M. W. (1989). Cognition (2d ed.). New York: Holt, Rinehart \& Winston.

Mayer, R. E. (1984). Twenty-five years of research on advance organizers. Instructional Science, 8, 133-169.

McDaniel, M., Einstein, G., \& Waddill, P. (1990). Material-appropriate processing: Implications for remediating recall deficits in students with learning disabilities. Learning Disability Quarterly, 13(4), $258-270$.

McGaugh, J. L., Cahill, L., Parent, M. B., Mesches, M. H., ColemanMesches, K., \& Salinas, J. A. (1995). Involvement of the amygdala in the regulation of memory storage. In Plasticity in the central nervous system: Learning and memory. Hillsdale, NJ: Erlbaum and Associates.

Mehring, T., \& Colson, S. (1993). Facilitating memory in students with learning disabilities. LD Forum, 16(1), 75-79.

Miller, G. A. (1956). The magical number seven, plus or minus two: Some limits on our capacity for processing information. Psychological Review, 63, 81-97.

Ogle, D. (1989). KWL: A teaching model that develops active reading of expository text. Reading Teacher, 39, 546-570.

Ormrod, J. E. (1998). Educational psychology: Developing learners. Columbus, OH: Prentice Hall.

Palincsar, A. S. (1984). The quest for meaning from expository text: A teacher-guided journey. In G. Duffy, L. H. Rohler, \& J. Mason (Eds.), Comprehension instruction: Perspectives and suggestions. New York: Longman.

Palincsar, A. S., \& Brown, A. L. (1986). Interactive teaching to promote independent learning from text. Reading Teacher, 39, 771-777.

Parks, S. \& Black, H. (1996). Organizing thinking: Graphic organizers. Pacific Grove, CA: Critical Thinking Press and Software.

Pearson, P. D., \& Fielding, L. (1991). Comprehension instruction. In R. Barr, M. Kamil, P. Mosenthal, \& P. D. Pearson, (Eds.). Handbook of reading research (Vol. 2). New York: Longman.

Pehrsson, R. S., \& Robinson, H. A. (1985). The semantic organizer approach to writing and reading instruction. Rockville, MD: Aspen Systems.

Perkins, D. and Salomon, G. (1992). The science and art of transfer. In A. L. Costa, J. A. Bellanca, \& R. Fogarty (Eds.), If minds matter: A forward to the future (Vol. 1). Palatine, IL: IRI/Skylight Publishing.
Peverly, S. T. (1991). Problems with the knowledge-based explanation of memory and development. Review of Educational Research, 6I(1), 71-93.

Pressley, M., \& Harris, K. R. (1994). What we really know about strategy instruction. Educational Leadership, 48(1), 31-34.

Project CRISS (Creating Independence Through Student-owned Strategies). (1996). Kalispell, MT. Kendall/Hunt.

Raphael, T. E. (1982) Question-answering strategies for children. Reading Teacher, 36, 186-190.

Readence, J. E., Bean, T. W., \& Baldwin, R. S. (1995). Content area reading: An integrated approach (5th ed). Dubuque, IA: Kendall/ Hunt.

Reed, S. K. (1992). Cognition (3d ed.). Pacific Grove, CA: Brooks/Cole.

Richardson, J., \& Morgan, R. (1994). Reading to learn in the content areas. Belmont, CA: Wadsworth.

Santrock, J. W. (1997). Life-span development. Dubuque, IA: Brown \& Benchmark.

Schneider, W. \& Shiffrin, R. (1977). Controlled and automatic human information processing: detection, search, and attention. Psychological Review, 84, 1-66.

Schunk, D. H. (1996). Goal and self-evaluative influences during childrens' cognitive skill learning. American Educational Research Journal, 33, 359-382.

Semb, G. B., \& Ellis, J. A. (1994). Knowledge taught in school: What is remembered. Review of Educational Research, 24, 253-286.

Simmonds, E. P. M. (1992). The effects of teacher training and implementation of two methods for improving the comprehension skills of students with learning disabilities. Learning Disabilities Research \& Practice 7, 194-198.

Slavin, R. E. (1991). Synthesis of research on cooperative learning. Educational Leadership, 48(5), 71-82.

Slavin, R. E. (1995) Cooperative Learning (2d ed.). Boston: Allyn \& Bacon.

Slavin, R. E. (1997). Educational psychology: Theory and practice. Boston: Allyn \& Bacon.

Snow, C. E., Burns, M. S., \& Griffin, P. (Eds). (1998). Preventing reading difficulties in young children. Washington, DC: National Academy Press.

Sorgen, M. (1998). Mind, memory, and learning: Applying brain research to classroom practice. Paper presented at Olathe District School Summer Conference, Olathe, KS.

Sowell, V. (1981). Teaching students with mild disabilities. Presentation at 23rd annual Kansas Learning Disabilities Conference, Wichita.

Stigler, S. M. (1978). Some long forgotten work on memory. Journal of Experimental Psychology: Human Learning and Memory, 4, 1-4.

Third international mathematics and survey study (1998). Washington, DC.: U.S. Government Printing Office.

Tierney, R. J., Readence, J. E., \& Dishner, E. K. (1995). Reading strategies and practices: A compendium. Boston: Allyn and Bacon.

Torgesen, J., Wagner, R., Simmons, K., \& Laughon, P. (1990). Identifying phonological coding problems in disabled readers: Naming, counting, or span measures? Learning Disability Quarterly, 13(4), 236-244.

Turnbull, A., Turnbull, H. R., Shank, M., \& Leal, D. (1995). Exceptional lives. Upper Saddle River, NJ: Prentice Hall.

U.S. Department of Education. (1997). Guidebook to examine school curricula, M. E. McNeeley (Ed.). Washington, DC: U.S. Government Printing Office.

Voss, J. F., \& Wiley, J. (1995). Acquiring intellectual skills. Annual Review of Psychology, 46, 155-181.

Winfield, A., \& Byrnes, D. L. (1981). The psychology of human memory. San Diego: Academic Press.

Winograd, P., \& Paris, S. (Dec./Jan. 1988-1989). A cognitive and motivational agenda for reading instruction. Educational Leadership, 46, 30-35.

Wollen, K. A., \& Lowry, D. H. (1974). Conditions that determine effectiveness of picture - mediated paired - association learning. Journal of Experimental Psychology, 102, 181-183.

Wolfe, P. (May, 1998). Direct connection (Newsletter) Lawrence: Kansas Staff Development Council.

Woolfolk, A. E. (1998). Educational psychology (7th ed). Boston: Allyn and Bacon. 